\title{
A EVOLUÇÃO DO DIREITO DE PROPRIEDADE E A FUNÇÃO SOCIAL DA PROPRIEDADE
}

\section{THE EVOLUTION OF PROPERTY RIGHTS AND SOCIAL FUNCTION OF THE PROPERTY}

\author{
${ }^{1}$ Vivian Valverde Corominas \\ ${ }^{2}$ José Marques Carriço
}

\section{RESUMO}

Este estudo aborda a evolução do direito de propriedade, alcançando os conceitos de função social da propriedade urbana e de direito à moradia, utilizando-se do método dedutivo. Partindo-se destes conceitos, como premissa maior, e dos elementos do direito de propriedade, demonstra-se a aplicabilidade do conceito de função social da propriedade às propriedades públicas e privadas, tornando-se este, um instrumento a ser observado pelas administrações públicas, na gestão das cidades, em busca do desenvolvimento sustentável.

Palavras-Chaves: Direito de propriedade; Função Social da Propriedade; Direito à moradia; Política habitacional; Desenvolvimento sustentável.

\begin{abstract}
This study addresses the evolution of property rights, until they get the concept of social function of urban property and housing rights, using the deductive method. Starting from these concepts, as major premise, and the elements of property rights, demonstrates the applicability of the concept of social function of property to public and private properties, becoming this, an instrument to be observed by the government in the management of cities, in pursuit of sustainable development.
\end{abstract}

Key-Words: Property right; Social Function of Property; Right to housing; Housing policy; Sustainable development.

\footnotetext{
${ }^{1}$ Mestranda em Direito Ambiental pela Universidade Católica de Santos - UNISANTOS, São Paulo (Brasil). Assessora Instituciona pela Prefeitura Municipal de Guarujá - PMGUARUJÁ, São Paulo (Brasil) E-mail: vivianvcadv@hotmail.com

${ }^{2}$ Doutor em Planejamento Urbano e Regional pela Universidade de São Paulo - FAU/USP, São Paulo (Brasil). Professor do Programa de Pós-graduação em Direito e do Curso de Arquitetura e Urbanismo pela Universidade Católica de Santos - UNISANTOS, São Paulo (Brasil). E-mail: §mc10557@gmail.com
} 


\section{INTRODUÇÃO}

As cidades ${ }^{3}$ e suas novas configurações devem ser vistas como oportunidades e não como problema. Assim, é fundamental estudar uma das questões centrais para os seus desenvolvimentos: a evolução do conceito de propriedade urbana, que transitou, durante o século passado, de um direito absoluto a um direito limitado por sua função social.

Atualmente, a função social da propriedade tem como escopo garantir a ordem dos espaços urbanos, de forma a se evitar os denominados vazios urbanos, normalmente objeto de especulação imobiliária.

Visando o uso sustentável do espaço urbano, da convivência das pessoas e até mesmo na garantia dos direitos daqueles menos favorecidos é que o direito de propriedade evoluiu, limitando-se pela função social.

Nesse sentido o Estatuto da Cidade ${ }^{4}$, em seu artigo $2^{\circ}$, dispõe as diretrizes gerais da política urbana, em especial a necessidade do planejamento do desenvolvimento das cidades, com adequada distribuição espacial da população e das atividades econômicas do município e do território sob sua área de influência, de modo a evitar e corrigir distorções do crescimento urbano e seus efeitos negativos sobre o meio ambiente. Acrescenta-se, ainda, a necessidade de ordenação e controle do uso do solo, de forma a se evitar a retenção especulativa de imóvel urbano, que resulte na sua subutilização ou não utilização, bem como a justa distribuição dos benefícios e ônus decorrentes do processo de urbanização.

Assim, não só o particular obriga-se a este múnus, como também o próprio Poder Público deve obediência ao princípio da função social da propriedade, pois, além de ser o responsável pela ordenação e controle do uso do solo, também é o garantidor da ordem, principalmente através do disposto em seu plano diretor.

Para tanto, o estudo em questão abordará os conceitos de direito à moradia, bem como o direito de propriedade e seus elementos, para então adentrar à função social da propriedade e se chegar à aplicação deste conceito às propriedades privadas e públicas, visto que, a função

\footnotetext{
${ }^{3}$ Segundo o Censo Demográfico de 2010, Fundação Instituto Brasileiro de Geografia e Estatística (FIBGE), 84\% da população brasileira vive em cidades e a previsão é de que, até o final da década, este percentual alcance $90 \%$. ${ }^{4}$ Lei Federal no 10.257 , de 10 de julho de 2001, que regulamenta os artigos 182 e 183 da Constituição Federal e estabelece diretrizes gerais da política urbana.
} 
social da propriedade, analisada de forma conjunta, visa garantir a função social da cidade e, consequentemente, a dignidade da pessoa humana.

\section{DIREITO À MORADIA E À HABITAÇÃO}

O direito à moradia, previsto na Declaração Universal dos Direitos Humanos; na Convenção Internacional dos Direitos Econômicos, Sociais e Culturais; bem como no artigo $6^{\circ}$, caput, da Constituição Federal, é um direito fundamental do ser humano, sendo considerado, inclusive, um direito da personalidade, de forma que seu exercício independe de um "objeto físico" para sua existência e proteção jurídica. (DE SOUZA, 2004)

Este direito, intimamente ligado à questão habitacional, até a sanção da Lei de Terras ${ }^{5}$, não importava para o Poder Público, pois a propriedade não havia adquirido status de mercadoria, e o processo de urbanização era incipiente, já que a economia assentava-se na agricultura, utilizando-se da mão-de-obra escrava. Neste período, cabia aos proprietários de latifúndios apenas fornecer aos escravos moradia, alimentação e assistência no caso de doenças. Não havia fluxo de mão-de-obra das zonas rurais para as urbanas e, portanto, a questão da moradia resolvia-se nas senzalas, com péssimas condições de salubridade.

Com a Lei de Terras, as propriedades passaram a ser registradas e a atender a lógica do nascente mercado imobiliário urbano, marcado pela escassez de terra urbanizada, em um quadro de rápido crescimento do êxodo rural e da importação de mão de obra europeia, que infla as cidades. Assim, a segunda metade do século XIX é marcada pelas péssimas condições de moradia dos trabalhadores que afluem as áreas urbanas, sem condições de aquisição de propriedades. Os cortiços, moradias coletivas de aluguel, caracterizadas pela alta densidade e péssimas condições de higiene, passam a ser a solução encontrada por milhares de migrantes e imigrantes, para viver nas proximidades do crescente mercado de trabalho.

Neste contexto, as epidemias passam a ser recorrentes nas grandes cidades brasileiras, provocando obstáculos à economia cafeeira, viabilizada pelo processo de urbanização. Assim, o Poder Público passou a se importar com as questões referentes à moradia, visto que as condições precárias em que viviam os trabalhadores era terreno fértil para a disseminação de doenças. No entanto, essa preocupação não dizia respeito às condições subumanas que

\footnotetext{
${ }^{5}$ Lei $\mathrm{n}^{\circ} 601$, de 18 de setembro de 1850 , que dispunha sobre as terras devolutas do Império.
} 
migrantes e imigrantes viviam nos sítios urbanos. Conforme Lanna (1996, p. 4), sobretudo em função da atuação da polícia sanitária, a questão habitacional era vista como caso de polícia. Segundo a autora, "tratava-se de afastar dos olhos aqueles diferentes com quem, inevitavelmente, dadas as condições de produção e reprodução do capitalismo, este espaço urbano tinha que ser compartilhado".

Mesmo tendo sido a higienização dos centros urbanos tratada, pelo Poder Público, como decorrência imediata de interesses econômicos, esta foi um primeiro passo à intervenção estatal na propriedade privada, quanto à questão da moradia. No final do século XIX, com o surgimento da indústria moderna, houve uma explosão demográfica nos centros urbanos, desencadeando, assim, uma crise habitacional nas grandes cidades. De acordo com Bonduki (1998), no campo da política habitacional, este período foi caracterizado pela omissão do Estado e por ações esporádicas de industriais que viam na construção de vilas operárias a saída para ampliar a eficiência da mão de obra fabril.

No século XIX, com a Revolução Industrial, na Europa e Estados Unidos, surgiu uma preocupação não mais com as liberdades públicas, $1^{\text {a }}$ Dimensão de Direitos Fundamentais, e sim com os direitos sociais, chamados Direitos Fundamentais de $2^{\text {a }}$ Geração. Desde então, a crise habitacional e o direito à moradia às populações menos favorecidas passaram a fazer parte das preocupações dos governos. No entanto, no Brasil, isto só vem a ocorrer no período de Getúlio Vargas, pois além de se tratar de um problema social que atingia grande parte da população, a intervenção no mercado habitacional garantia popularidade ao governo e assentava as bases de um capitalismo industrial, de feições urbanas, que requeria a migração maciça de trabalhadores rurais para as cidades.

Desta forma, com intuito de equilibrar as relações entre proprietários e inquilinos, o Governo congelou os aluguéis residenciais, afetando enormemente o mercado imobiliário, que deixou de produzir para fins residenciais, agravando ainda mais a questão habitacional. Como descreveu Bonduki (1998), nos anos 1940, o congelamento dos aluguéis representou um marco na história da provisão habitacional, no Brasil. Se de um lado desestimulou a produção rentista, por outro estimulou a ação dos Institutos de Aposentadoria e Pensão e promoveu a criação da Fundação da Casa Popular.

No mesmo período, a sociedade passou a ser estimulada pelo "sonho da casa própria", que permanece sendo uma das maiores ambições da população. Este é o estopim para a 
aceitação da produção de moradias em loteamentos periféricos, por vezes clandestinos e quase sempre sem infraestrutura, ou em favelas, resultantes da ocupação de áreas normalmente desprezadas pelo mercado imobiliário.

No entanto, a provisão habitacional estatal somente foi institucionalizada de forma efetiva, no País, com o Sistema Financeiro de Habitação (SFH), durante os governos militares, que instituem o Banco Nacional da Habitação $(\mathrm{BNH})^{6}$, responsável por expressiva produção habitacional, minoritariamente direcionada para a população de baixa renda. A partir dai, incrementa-se a construção de conjuntos habitacionais, usualmente construídos em áreas periféricas, em face do baixo custo dos terrenos. Este processo é responsável pela segregação socioespacial de milhões de famílias, entre as décadas de 1960 e 1980, quando o BNH foi desmontado, em razão da grave crise de gestão.

As décadas seguintes são marcadas pela ausência de uma política habitacional em nível nacional. Neste contexto, o Estado de São Paulo constitui-se exceção, em virtude da criação da Companhia de Desenvolvimento Habitacional e Urbano do Estado de São Paulo (CDHU), em 1989, a partir da antiga Companhia Estadual de Casas Populares (CECAP), fundada durante o governo militar. Com recursos do Imposto sobre Circulação de Mercadorias, diversos programas habitacionais passaram a ser promovidos no Estado, ainda que sem apoio de uma política nacional. Foi apenas na década passada que o Governo Federal retomou o incentivo a construção de habitações populares, com a criação do Ministério das Cidades, em 2003, do Fundo Nacional de Habitação de Interesse Social (FNHIS) ${ }^{7}$, e do programa "Minha Casa, Minha Vida" (MCMV) ${ }^{8}$, que se tornou um programa mais efetivo, aos adquirentes dos imóveis e ao credor fiduciário, do que os programas que o antecederam.

Nesta mesma linha, incentivou-se, a regularização fundiária de assentamentos e a requalificação dos imóveis urbanos, para a garantia da dignidade da pessoa humana, através da concessão de títulos a posseiros, desde que preenchidas as condicionantes legais, bem como tornar as habitações existentes com o mínimo de condições de moradia; conforme se verifica da Lei n. ${ }^{\circ} 11.977 / 2009^{9}$, que além de incentivar a construção de habitações populares, ainda aborda os aspectos da regularização fundiária e da requalificação de imóveis urbanos.

\footnotetext{
${ }^{6}$ O BNH foi criado pela Lei Federal no 4380, de 21 de agosto de 1964.

${ }^{7}$ O FNHIS foi criado pela Lei Federal no 11.124 , de 16 de junho de 2005.

${ }^{8}$ O programa MCMV foi criado pela Lei Federal no 11.977 , de 7 de julho de 2009.

${ }^{9}$ Alterada recentemente pela Medida Provisória n ${ }^{\circ}$ 759/2016.
} 
Com a evolução dos programas habitacionais, ao longo dos anos, ainda que insuficientes para atender a demanda, observa-se uma constante preocupação estatal com o direto à moradia, que não consiste somente no direito à habitação propriamente dita, mas também ao direito fundamental à dignidade humana. Em outras palavras, o direito à moradia, conforme os diversos diplomas legais prescrevem, consiste no direito a uma habitação digna, bem localizada e que apresente as mínimas condições necessárias ao acesso do ser humano aos benefícios do processo de urbanização.

No entanto, para que se garanta a moradia digna em grandes cidades, é necessário haver um ordenamento territorial adequado, buscando-se conferir a cada espaço urbano a sua função social adequada, observando-se, assim, o planejamento urbano advindo, principalmente, dos ditames estabelecidos no plano diretor, garantindo a função social da cidade.

\section{DIREITO DE PROPRIDADE}

Para se compreender o conceito de função social da propriedade, é preciso recuperar o contexto histórico dos elementos constitutivos do direito a propriedade, pois a evolução deste, do seu caráter absoluto ao relativo, ocorreu em razão das mudanças do processo de urbanização, assim como de mudanças políticas e sociais.

\subsection{Aspectos históricos do direito de propriedade}

O direito de propriedade, ao longo da história, passou por diversas fases: primeiramente dotado de um caráter individualista; depois social e, posteriormente, retomando seu caráter individual, até se chegar a estrutura atual, em que este direito guarda traços de individualidade, mas com limitações sociais ao seu exercício.

Nos primórdios das civilizações ocidentais, a propriedade do solo pertencia a toda uma comunidade que habitava um determinado espaço de assentamento. Tratava-se da propriedade coletiva da terra. Mais tarde, o sentido de propriedade individual surgiu com o direito romano, mais especificamente com o fortalecimento da autoridade do pater famílias (detentor do poder sobre coisas e pessoas), sendo que, aos poucos, foi aniquilada a propriedade vinculada ao culto dos antepassados, baseada na configuração da sociedade em famílias, gens e tribos, (COULANGES, 2009). 
Para se chegar ao estágio de propriedade privada, o direito de propriedade passou por quatro etapas: $1^{\mathrm{a}}$ ) propriedade individual sobre os objetos necessários à existência de cada um; $2^{a}$ ) propriedade individual sobre os bens de uso particular, suscetíveis de serem trocados com outras pessoas; $3^{\circ}$ ) propriedade dos meios de trabalho e de produção; $4^{\text {a }}$ ) propriedade individual nos moldes capitalistas de forma que seu dono pode explorá-la de forma absoluta. (DINIZ, 2002). Ressalte-se que a propriedade era indissociável da posse, de modo que, sem esta, o direito à coisa não existia.

Na Idade Média, a propriedade passou a ter dualidade de sujeitos, de forma que os nobres da época, como forma de retribuir àqueles que lhes prestavam algum serviço, inclusive militares, concediam porções de terras a estas pessoas em forma de usufruto condicional, surgindo, assim, os feudos. Com o tempo, a propriedade destas terras tornou-se perpétua e transmissível através da linha masculina. Era o denominado instituto do morgado, em que as mulheres não herdavam, sendo certo que, o aspecto mais marcante da propriedade nesta época a exploração econômica do imóvel pelo dono, pagando-se a este pelo seu uso.

Em 1789, com a Revolução Francesa, houve a abolição da servidão e dos direitos feudais passando a propriedade a ter uma feição marcadamente individualista, isto porque, nesta nova era a burguesia rebelou-se contra os privilégios que o clero e os nobres detinham, reivindicando, assim, o disposto no lema dos revolucionários “Liberdade, Igualdade e Fraternidade" no tocante aos seus direitos, inclusive quanto ao direito de propriedade. Neste mesmo ano foi aprovada a "Declaração dos Direitos do Homem e do Cidadão", que dava um caráter absoluto ao direito de propriedade, passando esta a ser um direito inviolável, sagrado.

No século XX, a propriedade passou a ter caráter social acentuado, contribuindo para isso as Encíclicas Papais, mais especificamente a Encíclica Rerum Novarum, do Papa Leão XIII, que defendia o direito à propriedade privada, segundo Gonçalves (2003).

Atualmente, pode-se afirmar que a propriedade tem caráter misto, pois a Constituição Federal em diversos dispositivos (art. 5 XXII e XXIII; 170,III; 182, §2 legislação infraconstitucional (Lei n ${ }^{\circ} .10 .257 / 01$, arts. $1^{\circ}$ ao $4^{\circ}$; Código Civil, arts. 1228, $\S \S 1^{\circ}$ ao $5^{\circ}$ ) não só limitam o direito de propriedade do indivíduo, como também o condiciona ao cumprimento de sua função social; deixando a propriedade de ser um direito subjetivo para se tornar um direito-dever, um múnus, conforme Diniz (2002). 


\title{
3.2. Elementos Constitutivos e Conceito de Direito de Propriedade
}

O artigo 1228 do Código Civil dispõe que o proprietário tem a faculdade de usar, gozar, dispor da propriedade, bem como reavê-la de quem quer que injustamente a possua ou detenha; sendo esses considerados os elementos constitutivos da propriedade, de modo que no tocante à disposição da coisa, somente o proprietário tem tal direito.

Ao prescrever sobre os poderes que o proprietário tem sobre a propriedade, o legislador delimita os elementos constitutivos desta, de forma que a ausência de um destes poderes faz com que o proprietário não tenha a propriedade plena sobre a res.

Note-se que a faculdade de dispor, como observado na história do direito de propriedade, era absoluta. Todavia, com a evolução do instituto, o que outrora era absoluto passou a ser limitado pela função social da propriedade, conforme artigo $5^{\circ}$, XXIII, da Constituição Federal. Em outras palavras, se o proprietário não der à sua propriedade função social, poderá ser "penalizado", podendo, até mesmo, vir a perder sua propriedade, sendo este o motivo pelo qual este elemento não é mais absoluto.

Portanto, conceituar o direito de propriedade não é das tarefas mais fáceis a serem enfrentadas pelos juristas; e esta dificuldade não vem de hoje. Os romanos encontraram empecilhos para conceituação, visto que os textos da Idade Média não mencionavam a propriedade, devendo estes hermeneutas extrair um conceito através da interpretação conjunta de diversos textos. Assim, chegaram a um conceito considerando diversas características da propriedade, que permanecem até hoje, conforme leciona Alves (1999, p. 281):

\begin{abstract}
Assim, com base num reescrito de Constantino (C. IV,35,21), relativo à gestão de negócios, definiram o proprietário como suae rei moderator et arbiter (regente e árbitro de sua coisa); de fragmento do Digesto (V,3,25,11), sobre o possuidor de boa-fé, deduziram que a propriedade seria ius utendi et abutendi re sua (direito de usar e de abusar da sua coisa); e de outra lei do Digesto (I,5,pr.), em que se define a liberdade, resultou a aplicação desse conceito à propriedade que, então, seria a naturalis in re facultas eius quod cuique facere libet, nisi si quid aut ui aut iure prohibetur (faculdade natural de se fazer o que se quiser sobre a coisa, exceto aquilo que é vedado pela força ou pelo direito)
\end{abstract}

E mesmo com estas interpretações, os romanos não conseguiram chegar a uma conceituação completa sobre o instituto. O mais próximo do que vem a ser a propriedade nesta época foi o conceito apresentado por Bonfante, em que a propriedade "é a senhoria mais geral sobre a coisa, seja em ato, seja pelo menos em potência" (ALVES, 1999, p. 281). Trata-se da 
concepção de que a propriedade é individual e absoluta, no sentido de que o pater famílias detinha soberania sobre a res.

Atualmente, a mesma dificuldade de conceituação é encontrada pelos juristas, não por ausência de previsão específica e legal do instituto, mas sim em decorrência dos múltiplos poderes e deveres do proprietário. Mas com a evolução doutrinária e legal, este aspecto de propriedade absoluta e inviolável foi superado, passando a propriedade a ser um direito limitado pelo interesse público, mais especificamente, pela função social da propriedade; sendo este direito composto pelas mencionadas faculdades de usar (jus utendi), gozar (jus fruendi), dispor (jus abutendi) e reaver a res, conforme o artigo 1228, caput, do Código Civil.

A Constituição Federal não conceitua o direito à propriedade, apenas delimita seu exercício em vista dos direitos fundamentais, impelindo o hermeneuta a buscar a interpretação numa visão global e sistêmica do ordenamento jurídico. O conceito legal de propriedade não foi prescrito por norma infraconstitucional, apenas sendo descrito o seu conteúdo, ao qual foram fornecidos elementos para que se pudesse compreendê-lo. Diante das premissas traçadas pela Constituição Federal sobre o direito de propriedade, bem como pelas disposições constantes da legislação e conclusões doutrinárias e jurisprudenciais é que se pode chegar a uma conclusão do conceito de propriedade.

Diniz (2002, p. 106) utiliza-se do conceito analítico de propriedade, baseado no conteúdo deste direito, como sendo "o direito que a pessoa física ou jurídica tem, dentro dos limites normativos, de usar, gozar e dispor de um bem, corpóreo ou incorpóreo, bem como de reivindicá-lo de quem injustamente o detenha". Assim, pode-se interpretar que a propriedade não tem mais caráter absoluto, devendo cumprir com sua função no âmbito da sociedade pois, se assim não ocorrer, poderá, até mesmo, o proprietário "perdê-la" para o Poder Público (subrogação, mediante o pagamento de justa indenização), como por exemplo, no caso de desapropriação prevista no artigo 182, $4^{\circ}$, III, da Constituição Federal.

Desta forma, com a evolução legislativa e com a preocupação crescente em se ter cidades que proporcionem bem estar aos seus habitantes, conforme preceitua o "caput", do artigo 182, da Carta Magna, verifica-se que o direito de propriedade passou a contar com mais um elemento, ou seja, a função social da propriedade. Assim, é necessário que a propriedade cumpra com sua função dentro da urbe, sob pena de incorrer nas sanções previstas no mencionado artigo 182. 


\section{FUNÇÃO SOCIAL DA PROPRIEDADE}

Segundo De Almeida e Medauar (2004), a ideia de que a propriedade deve cumprir sua função social não é nova, todavia, o instituto da função social da propriedade ganhou forças com a posição adotada por Leon Duguit, que defendia que todo indivíduo tem uma determinada função a desempenhar na sociedade, de forma que todos os atos realizados contrários à esta função seriam socialmente reprimidos e, a contrário senso, os atos que obedecessem esta tarefa seriam socialmente protegidos e garantidos.

No ordenamento jurídico brasileiro, a preocupação em dar uma função à terra, remonta à época em que o Brasil era colônia lusitana. Isso porque, naqueles tempos, segundo Nery e Viana (2000), após o fracasso da divisão do território da colônia em Capitanias Hereditárias, passou a ser adotado o regime das sesmarias, que condicionava a concessão de terras ao aproveitamento útil e econômico desta. Posteriormente, com a Lei de Terras, disciplinava-se a retomada das terras que não se tinha dado o devido aproveitamento.

Todavia, esta preocupação em dar uma função a terra não foi adotada pela Carta Imperial de 1824 e pela Carta Republicana de 1891, somente retornando ao ordenamento a obrigatoriedade em se observar o interesse social e coletivo na Constituição de 1934; ao passo que a Constituição Federal de 1946 condicionou a propriedade ao bem estar social e a justa distribuição da propriedade. Interessante notar que neste texto constitucional o direito de propriedade é tratado como direito e garantia fundamental, como na Constituição antecedente, mas é inserido no Capítulo da Ordem Econômica e Social.

No entanto, foi com a Constituição de 1967 que o direito de propriedade manteve-se como direito fundamental, sendo instituída expressamente a função social da propriedade como princípio da Ordem Econômica e Social. Mesmo com a Emenda Constitucional n. ${ }^{\circ}$ 1, de 1969, que alterou substancialmente o texto constitucional, estas disposições permaneceram sem modificação.

Após o período da ditadura militar, buscando-se preservar os direitos e garantias fundamentais tolhidos no regime anterior, foi sancionada a Constituição Federal de 1988, que, em seu artigo $5^{\circ}$, assegura aos brasileiros e estrangeiros residentes no País a inviolabilidade do direito à propriedade, enfatizando esta garantia no inciso XXII, do mesmo artigo.

Em primeira análise, poder-se-ia alegar que a Constituição Federal manteve o mesmo conceito de propriedade adotado pelo Código Napoleônico e Código Civil de 1916, que 
caracterizavam a propriedade como absoluta. No entanto, percebe-se que o constituinte acrescentou um elemento ao conceito de propriedade ao dispor, no inciso XXIII, do citado artigo $5^{\circ}$, que "a propriedade atenderá sua função social". Este artigo trata da função social da propriedade de forma genérica, ou seja, tanto a propriedade rural quanto da urbana. Então, no que consiste a função social da propriedade?

É verdade que a Constituição Federal não dispõe sobre o conceito de função social da propriedade, mesmo porque, esta tarefa não cabe a ela e sim à legislação ordinária, à doutrina e jurisprudência. Todavia, ela nos fornece diretrizes sobre a função social da propriedade, de forma que os parâmetros de avaliação do cumprimento desta em relação à propriedade urbana são distintos dos da rural. No Capítulo que trata da política agrícola, fundiária e de reforma agrária, prescreve, em seu artigo 184, “caput”, que para fins de reforma agrária, a União poderá desapropriar por interesse social a propriedade rural que não estiver cumprindo com sua função social; e acrescenta no parágrafo único, do artigo 185, que "a lei garantirá tratamento especial à propriedade produtiva e fixará normas para o cumprimento dos requisitos relativos a sua função social."

De fato, no tocante à propriedade rural, a Carta Magna dispõe em seu artigo 186 e incisos, que esta função somente será cumprida quando, de forma simultânea, atender aos requisitos de aproveitamento racional e adequado; utilização adequada dos recursos naturais disponíveis e preservação do meio ambiente; observância das disposições que regulam as relações de trabalho; bem como a exploração que favoreça o bem-estar dos proprietários e dos trabalhadores. Porém, o cumprimento da função social da propriedade rural não é inovação da Constituição Federal, pois esta limitação existia desde o Estatuto da Terra ${ }^{10}$.

A mencionada norma, ainda em vigor, prescreve em seu artigo $2^{\circ}$, que "é assegurada a todos a oportunidade de acesso à propriedade da terra, condicionada pela sua função social, na forma prevista nesta Lei”; e complementa em seu parágrafo $1^{\circ}$, descrevendo os requisitos para cumprimento da função social da propriedade rural, destacando serem eles: a) favorecimento do bem-estar dos proprietários, trabalhadores e seu familiares que labutam na terra; b) manutenção de níveis satisfatórios de produtividade; c) garantia da conservação dos recursos naturais; d) observância às normas que regulam as justas relações de trabalho entre os que possuem e os trabalhadores.

\footnotetext{
${ }^{10}$ Lei Federal no 4.504, de 30 de novembro de 1964.
} 
Os requisitos acima elencados, que devem ser observados de forma simultânea, bem como os requisitos previstos na Constituição Federal, são extremamente subjetivos, de forma a dificultar a ação do Poder Público de expropriar àqueles que não estiverem dando à sua propriedade a devida função social. Por outro lado, com o escopo de garantir o direito à moradia àqueles que vivem no campo e, assim, evitar que estes migrem para as urbes, a Constituição Federal, sob o fundamento da função social da propriedade, prescreve em seu artigo 191, “caput", sobre a possibilidade da usucapião pro labore, em que visa privilegiar aquele pequeno produtor que está dando função social à terra; e punir o proprietário desidioso.

Em suma, a caracterização do descumprimento da função social pela inobservância dos requisitos constitucionais e infraconstitucionais e, consequentemente, a expropriação do particular para fins de reforma agrária por estes motivos é tarefa árdua devido à subjetividade dos elementos.

Contrapondo-se a isso, o legislador constituinte garantiu o direito à moradia aos pequenos produtores que derem uma utilidade à terra improdutiva, garantindo-lhes não só o direito a moradia, como o próprio sustento, princípio da dignidade da pessoa humana.

\subsection{Função social da propriedade urbana}

$\mathrm{O}$ artigo $5^{\circ}$, XXIII, da Constituição Federal de 1988, assegura o direito de propriedade, que antes era absoluto, passando a ser limitado à função social. Porém, como salientado, no que tange aos requisitos, a função social da propriedade rural é distinta da urbana, pois são diferentes os espaços e atividades a que estão sujeitas, bem como os interesses com relação a cada tipo de propriedade.

No que tange a propriedade rural, o intuito é evitar grandes latifúndios, terras improdutivas. Quanto à propriedade urbana, busca-se evitar os vazios urbanos, espaços que podem ter aproveitamento mais produtivo e socialmente adequado, caso ocupados.

De acordo com o $\S 2^{\circ}$, do artigo 182, da Constituição Federal, a propriedade cumprirá sua função social quando respeitadas as regras expressas no plano diretor; complementando, em seu $\S 1^{\circ}$, que este será obrigatório para cidades com mais de vinte mil habitantes.

A competência do Município para tratar da matéria também tem fundamento constitucional, já que a Constituição Federal lhe concede competência privativa para legislar 
sobre assunto de interesse local (art. 30, I) e "promover no que couber, adequado ordenamento territorial, mediante planejamento e controle do uso, do parcelamento e da ocupação do solo urbano" (artigo 30, VIII).

Em suma, com a Constituição Federal de 1988, o plano diretor tornou-se "instrumento básico da política urbana do Município, que tem por objetivo ordenar o pleno desenvolvimento das funções sociais da cidade e garantir o bem-estar da comunidade local" (art. 182). Assim, a obrigatoriedade da observância do plano diretor para cumprimento da função social faz todo o sentido.

Diante da premissa apresentada acima, poder-se-ia entender que as cidades com menos de vinte mil habitantes estariam dispensadas da implantação de um plano diretor, tornando-se, assim, uma faculdade do Município. Todavia, o Estatuto da Cidade estabeleceu que, em alguns casos, independentemente do número de habitantes no Município, o plano diretor será obrigatório, conforme dispõe seu artigo 41 e incisos.

Assim, indaga-se se poderia uma lei ordinária restringir o disposto na Constituição Federal, haja vista esta ter imposto, como único requisito, a obrigatoriedade de plano diretor à existência de mais de vinte mil habitantes, não prescrevendo qualquer obrigatoriedade aos municípios com número de habitantes inferior ao mencionado.

Em outras palavras, um município com número menor de habitantes, mas que seja estância turística, por exemplo, pela Constituição Federal teria a faculdade de elaborar e implantar seu plano diretor. Por outro lado, pelo Estatuto da Cidade, este mesmo Município teria a obrigação de fazê-lo. Neste sentido a hermenêutica constitucional prescreve que as exceções impostas pela Magna Carta devem ser analisadas de forma restritiva. Assim, o Estatuto da Cidade não poderia ampliar hipóteses de obrigatoriedade de plano diretor previstas na Constituição.

Há, ainda, discussão envolvendo a violação ao princípio da autonomia municipal, devido à mencionada imposição. Na Ação Direita de Inconstitucionalidade (ADI) n. ${ }^{\circ} 826$ AP, a Advocacia Geral da União defende que a Constituição Federal foi omissa quanto a municípios com menos de vinte mil habitantes, não impedindo que esta obrigatoriedade fosse imposta por lei federal ou estadual, conforme texto abaixo: 
O Exmo. Sr. Advogado-Geral da União ratificou a manifestação da Assembleia Legislativa do Estado do Amapá e ainda produziu as seguintes razões:

“(...)

Convém ressaltar, ainda, que a Constituição Federal refere-se, tão somente, à obrigatoriedade do citado plano diretor para cidades com mais de vinte mil habitantes, sendo omissa no que tange à cidade com número inferior.

Ora, por questões sociais, de inegável importância, nada impede que os Estados incluam em seus Estatutos Políticos a obrigatoriedade de aprovação daqueles planos para as demais cidades, estabelecendo critério de acordo com um número de habitantes que julguem conveniente.

Releva lembrar, também, que tais planos diretores, consoante quer a Carta do Estado do Amapá, serão aprovados pelas próprias Câmaras Municipais, como previsto na Lei Fundamental Federal, sem nenhuma ingerência dos Poderes Executivos e Legislativo Estadual".

Outro argumento relevante para esta corrente é que o Estatuto da Cidade repete o que fora previsto no artigo 182 , parágrafos $1^{\circ}$ e $4^{\circ}$, da Constituição Federal, tendo em vista que este ente tem competência para expedir normas gerais de direito urbanístico (artigo 24, $1^{\circ}$, da Constituição Federal), em que está calcado o poder de impor a obrigatoriedade de plano diretor à Municípios que apresentem certas características.

Por outro lado, tem-se a corrente adotada pelo Supremo Tribunal Federal, na ação mencionada ADI, que entende que impor a exigência de plano diretor para municípios com menos de 20.000 habitantes, seria um afronto ao princípio da autonomia dos municípios; sendo certo que o ministro-relator Dr. Sydney Sanches, em seu voto, acrescentou que o Estatuto da Cidade "invadiu a área de competência de tais municípios, que na Constituição não sofrera limitações, a respeito".

Todavia, na prática, essa discussão é irrelevante no que tange às regiões mais desenvolvidas, sobretudo regiões metropolitanas, posto ser muito difícil a existência de município sem plano diretor, visto ser esse o mais importante instrumento de política urbana. Mas não se pode descartar a existência de município com menos de vinte mil habitantes, que não se enquadre na hipótese prevista no Estatuto da Cidade, em que seja obrigatória a existência de plano diretor. Neste caso, como a propriedade urbana cumpre sua função social?

A resposta é simples, o município não poderá punir o proprietário do imóvel por mau uso deste devido a ausência de norma. Sendo assim, conclui-se que a norma constitucional que determina a observância da função social, neste caso, excepcionalmente, será uma norma de eficácia limitada, cabendo, até mesmo a impetração de mandado de injunção para o Município regulamentá-la. 
Porém, o plano diretor instrumentaliza o planejamento urbano, pois define os requisitos da função social da propriedade urbana, bem como as condições e requisitos para uso, edificação e reforma de imóveis. Ou seja, o plano diretor contempla os elementos básicos para a ordenação do solo urbano, sendo, posteriormente, regulamentado em leis próprias.

De forma legalista, para se verificar o cumprimento da função social de um imóvel urbano, é preciso observar se este tem adequado aproveitamento do solo, obedecendo aos coeficientes mínimos de aproveitamento definidos no plano diretor, sob pena de ser considerado não edificado, subutilizado ou não utilizado, suscetível ao parcelamento, edificação ou utilização compulsórios, conforme os artigos $5^{\circ}$ e $6^{\circ}$ do Estatuto da Cidade.

No entanto, há uma discussão doutrinária quanto ao condicionamento da função social à observância dos coeficientes mínimos de aproveitamento. Há a corrente clássica, defendida pela professora Odete Medauar e outros administrativistas que entendem que só há cumprimento da função social da propriedade se observados potenciais mínimos de aproveitamento do solo, de forma que um terreno só seria considerado utilizado se edificado. Por esta linha, entende-se que o direito de construir e o direito de propriedade confundem-se, sendo um inerente ao outro,

Da Silva (2010), ao mencionar Hely Lopes Meirelles, complementa aduzindo que o “direito de construir" é inerente ao direito de propriedade do terreno, de forma que aquele constitui uma das faculdades do direito de propriedade, posto que nos elementos da propriedade (uso, gozo e disponibilidade) está compreendida a faculdade de transformá-la, edifica-la, beneficiá-la, com todas as obras que lhe favoreçam a utilização ou aumento de seu valor econômico. Trata-se do conceito francês de utilização do solo urbano, de forma que não se tem adequado aproveitamento do solo sem edificação/construção, equiparando-se, assim, o conceito de utilização com o conceito de construção.

Contrapondo-se a esta corrente, há o conceito americano de utilização do solo que consiste no aproveitamento econômico deste, isto é, solo utilizado é aquele que possui aproveitamento econômico, independentemente deste ser edificado ou não ${ }^{11}$.

A tendência da doutrina e da jurisprudência brasileira é a de adotar uma corrente mista, que se pode denominar de corrente franco-americana de utilização do solo urbano. Por este posicionamento, adota-se o conceito de utilização socialmente adequada do solo urbano, em

\footnotetext{
${ }^{11}$ Há algumas atividades econômicas que podem ser exercidas em imóveis urbanos, as quais prescindem de edificações, ou de edificações que atinjam determinado coeficiente mínimo, como postos de abastecimento de combustíveis, terminais portuários etc.
} 
que pode se ter uma área não edificada, mas de extrema relevância, como áreas verdes etc. $\mathrm{O}$ próprio Estatuto da Cidade adotou este conceito de propriedade que dissocia direito de propriedade do direito de construir, ao prever, em seu artigo 35, a transferência do direito de construir como instrumento específico de política urbana.

Nesse sentido, o Plano Diretor Estratégico do Município de São Paulo admite formas de utilização do solo urbano que não sejam necessariamente a construção. Portanto, nesta ótica o cumprimento da função social da propriedade não está somente relacionado ao conceito de coeficiente mínimo de aproveitamento, mas ao conceito de utilização socialmente adequada do terreno, que se caracterizará através da subsunção da utilização com as disposições do plano diretor, para o zoneamento onde se encontra o imóvel.

Assim, quando verificada pelo município a inobservância da utilização socialmente adequada do solo, para impelir o proprietário do imóvel a dar cumprimento a esta, pode-se utilizar o parcelamento, edificação ou utilização compulsórios do solo urbano. Para tanto, o município notificará o proprietário, conforme o caso, sob pena de incorrer nas sanções previstas no Estatuto da Cidade, que pode levar até mesmo à desapropriação do bem (artigo $8^{\circ}$, da Lei n. $\left.{ }^{\circ} 10.257 / 01\right)$.

\subsection{Função Social da propriedade pública}

A Constituição Federal determina o cumprimento da função social da propriedade, estabelecendo diretrizes gerais sobre esta e parâmetros distintos de cumprimento desta em relação à propriedade rural e urbana, sem diferenciar propriedade privada e pública. Partindo dessa premissa, pode-se concluir que a função social da propriedade deve ser atendida tanto pela propriedade privada, quanto pela pública, de forma que ambas, quando urbanas, devem atentar às imposições impostas pelo plano diretor.

No entanto, a forma de atendimento ao disposto no plano diretor é diversa para propriedade pública e para privada, isto porque, o princípio da legalidade é aplicado de forma distinta para o particular e para administração pública. Ao particular, conforme prescreve o artigo $5^{\circ}$, II, da Constituição Federal, “ninguém será obrigado a fazer ou deixar de fazer alguma coisa senão em virtude de lei", isto significa que o particular pode fazer tudo, exceto o que a lei proibir; há uma liberdade de atuação limitada pelas vedações legais. Para a administração pública, o princípio da legalidade (artigo 37, C.F.) assume uma ótica mais restritiva, ou seja, o 
Poder Público só pode agir dentro dos ditames legais, de forma que a ausência de previsão legal engessa a atuação daquele.

Partindo destas distinções, a propriedade pública cumprirá com a função social quando obedecer aos requisitos legais, ou seja, quando o Poder Público der ao bem público sua destinação legal. Portanto, para se constatar o cumprimento da função social por um bem público, obrigatoriamente, é necessário saber diante de qual espécie de bem público se está.

O artigo 99, do Código Civil, estabelece como bens públicos os de uso comum do povo, os de uso especial e os dominicais. Por esta vertente, há que distingui-los por serem essenciais à fixação do conteúdo da função social de cada espécie.

a) Bens de uso comum do povo: são aqueles em que há utilização concorrente por todos (fruição coletiva), não havendo um usuário determinado; salvo no caso de prévia autorização do Poder Público, em que se atenda ao interesse público, poderá se ter o uso restritivo desde que breve e transitório.

b) Bens de uso especial: são os utilizados para cumprimento de uma função pública; ou seja, “vinculados a uma utilização específica (como as universidades públicas), à prestação de um serviço público (hospital público) ou ocupação por órgãos da própria administração (repartições públicas)."

c) Bens dominicais (dominiais): nos termos do parágrafo único, do artigo 99, do Código Civil, são "os bens pertencentes às pessoas jurídicas de direito público a que se tenha dado estrutura de direito privado", ou seja, os que compõem o patrimônio disponível da Administração Pública.

De acordo com Meirelles (2002), estes bens não têm destinação pública determinada e tampouco um fim específico, de forma que bens de outras espécies poderão ser transferidos para esta categoria quando forem desafetados de sua primitiva finalidade pública, para subsequente alienação. Desta forma, os bens públicos cumprem sua função social quando obedecidas as destinações acima mencionadas. Nesse sentido, Di Pietro (2006, p.12) já se manifestou:

Pelo exposto se conclui que a ideia de função social, envolvendo o dever de utilização, não é incompatível com a propriedade pública. Esta já tem uma finalidade pública que lhe é inerente e que pode e deve ser ampliada para melhor atender ao interesse público, em especial aos objetivos constitucionais voltados para o pleno desenvolvimento das funções da cidade e à garantia do bem-estar de seus habitantes. 
No que tange aos bens dominiais, estes cumprirão com sua função social quando servirem de reserva patrimonial e fundiária ao ente federado.

Importante notar que dizer que o bem público tem que cumprir com sua função social, significa impor um ônus à administração pública, no sentido de que o cumprimento da função social desta está condicionado às diretrizes fixadas não só pela Carta Magna, como também pelo Estatuto da Cidade, no sentido de garantir aos cidadãos o desenvolvimento das funções sociais das cidades.

O princípio da função social da propriedade pública não está consagrado com tanta clareza na Constituição. Ele não é definido senão por meio de diretrizes a serem observadas pelo poder público. Ele está sintetizado no artigo 182. O dispositivo coloca como objetivo da política de desenvolvimento urbano "o pleno desenvolvimento das funções sociais da cidade e garantir o bem-estar de seus habitantes" (DI PIETRO, 2006, p. 3)

Portanto, a função social da propriedade pública, além de atentar ao critério da destinação dos bens públicos, deve, ainda, observar as determinações fundamentais no que tange às ordenações da cidade, sob pena de serem promovidas ações populares ou ações civis públicas com o escopo de coagir o Poder Público a cumprir com a função social de seus bens.

\section{CONCLUSÃO}

A preocupação em garantir o direito à moradia aos seres humanos, garantindo-lhes dignidade como pessoa, conforme determina a Declaração de Direitos Humanos, dentre outros tratados internacionais existentes, bem como a Constituição Federal de 1988, é um dos principais objetivos constantes dos programas de governo de qualquer esfera. Isto porque, a questão, além de ser um problema social a ser enfrentado por atingir grande parte da população brasileira, confere popularidade aos governos e, principalmente, garante a reprodução do regime capitalista baseado no processo de urbanização.

Assim, visando à redução do déficit habitacional e do crescimento da indústria da construção civil, o governo federal criou programas federais importantes, para facilitar o acesso à aquisição da "casa própria", como a Fundação da Casa Popular, o Sistema Financeiro de Habitação, PAC Favelas e o Programa Minha Casa Minha Vida. Estes programas exigiram a construção de um ordenamento jurídico próprio, que facilitou a concretização de suas metas, sem, contudo, resolver o enorme passivo habitacional que caracteriza o Brasil.

Importante salientar que mencionados programas visam auxiliar, por meio de financiamentos em longo prazo ou subsídios, inclusive a fundo perdido, dependendo da faixa 
de renda familiar, as pessoas na aquisição de propriedade. Todavia, estes programas não lograram sucesso em resolver a situação da maioria daqueles que residem de forma irregular em assentamentos precários implantados em áreas particulares ou públicas.

Essa questão passa a ser tratada pelo ordenamento jurídico brasileiro através do Estatuto da Cidade, que prevê diversos instrumentos de política urbana que visam reordenar as ocupações irregulares, inclusive de áreas públicas.

Assim, ao prover a moradia ou regularizar a situação dessas famílias que se encontram em assentamentos precários, o Poder Público está dando função social à propriedade, seja ela privada ou pública. Igualmente importante é garantir que a propriedade urbana cumpra a função social, de forma a garantir a utilização de terrenos, sobretudo em áreas bem localizadas, para moradia.

Contudo, há que se ressaltar que, a destinação dos bens públicos para garantia do direito a moradia só é possível para bens dominiais, pois são aqueles que se encontram no patrimônio disponível do Poder Público.

O Poder Público, responsável pelo ordenamento do solo urbano, bem como do seu parcelamento, consequentemente é responsável por garantir que esses espaços tenham sua destinação adequada, alcançando seus coeficientes mínimos de aproveitamento ou possuindo atividades econômicas, punindo aqueles que não deem função aos seus imóveis. Este Poder deve, também, atentar-se às áreas públicas, dando destinação legal a elas, sob pena de serem promovidas ações populares ou ações civis públicas com o escopo de coagi-lo a cumprir com a função social de seus bens.

Portanto, a função social da propriedade é o elemento primordial a ser observado tanto pelos particulares, como pela administração pública, para garantir o desenvolvimento sustentável, sob pena de incorrerem em penalidades legais e perpetuação do quadro de déficit habitacional que marca o Brasil. 


\section{REFERÊNCIAS BIBLIOGRÁFICAS}

ALVES, José C. Moreira. Direito Romano, volume I: História do Direito Romano, Instituições de Direito Romano. 12ª ed. Rio de Janeiro: Forense, 1999.

BONDUKI, Nabil. Origens da habitação social no Brasil. São Paulo: Estação Liberdade, 1998.

BRASIL (Governo). Constituição Federal (1934). Disponível em: www.planalto.gov.br

. Constituição Federal (1946). Disponível em: www.planalto.gov.br

Lei $n^{\circ} 4380$, de 21 de agosto de 1964. Cria o Banco Nacional da Habitação (BNH), e Sociedades de Crédito Imobiliário, as Letras Imobiliárias, o Serviço Federal de Habitação e Urbanismo Disponível em: www.planalto.gov.br

em: www.planalto.gov.br

Lei n ${ }^{\circ} 4.504$, de 30 de novembro de 1964. Estatuto da Terra. Disponível . Constituição Federal (1967). Disponível em: www.planalto.gov.br

.Constituição Federal (1988). Disponível em: www.planalto.gov.br

BRASIL (Império). Lei de Terras. Lei nº 601, de 18 de setembro de 1850. Dispõe sobre as terras devolutas.

- Estatuto da Cidade (Lei $\mathrm{n}^{\circ} 10.257$, de 10 de julho de 2001). Regulamenta os artigos 182 e 183 da Constituição Federal e estabelece diretrizes gerais da política urbana. Disponível em: www.planalto.gov.br www.planalto.gov.br

.Código Civil (Lei n ${ }^{\circ} 10.406$, de 10 de janeiro de 2002). Disponível em:

Sistema e Fundo Nacional de Habitação de Interesse Social. Lei Federal n 11.124, de 16 de junho de 2005. Disponível em: www.planalto.gov.br

. Programa Minha Casa Minha Vida. (Lei n ${ }^{\circ} 11.977$, de 7 de julho de 2009). Disponível em: www.planalto.gov.br

www.planalto.gov.br

Medida Provisória n. ${ }^{\circ}$ 759, de 22 de dezembro de 2016. Disponível em:

BRASIL (Judiciário). Ação Direita de Inconstitucionalidade n. $^{\circ} 826$ AP. Jurisprudência. Disponível em: www.stf.jus.br

BRASIL. (Portal Brasil). Total de habitantes das áreas urbanas cresce e chega a $84,4 \% \mathrm{em}$ 2010. 2011. Disponível em: http://www.brasil.gov.br/economia-e-emprego/2011/04/total-dehabitantes-das-areas-urbanas-cresce-e-chega-a-84-4-em-2010. Acesso em: 11 jan. 2017. 
COULANGES, Numa-Denys Fustel de. A cidade antiga: estudo sobre o culto, o direito e as instituições da Grécia e de Roma. São Paulo: Martin Claret, 2009.

DA SILVA, José Afonso. Direito Urbanístico Brasileiro. $6^{\mathrm{a}}$ ed. rev. e atual., São Paulo: Malheiros, 2010.

DE ALMEIDA, Fernando D. Menezes; MEDAUAR, Odete (coord.). Estatuto da Cidade: Lei 10257, de 10.07.2001, Comentários. 2a . ed. rev., atual. e ampl., São Paulo: Ed. Revista dos Tribunais, 2004.

DE SOUZA, Sérgio Iglesias Nunes. Direito à moradia e de habitação: análise comparativa e suas implicações teóricas e práticas com os direitos da personalidade. São Paulo: Ed. Revista dos Tribunais, 2004.

DI PIETRO, Maria Sylvia Zanella. Função Social da Propriedade Pública. Revista Eletrônica de Direito do Estado. Salvador. Instituto de Direito Público da Bahia. n. ${ }^{\circ}$ 6, abril/maio/junho, 2006. Disponível na internet: http://www.direitodoestado.com.br Acesso em: 16 de setembro de 2016

DINIZ, Maria Helena. Direito Civil Brasileiro, volume 4: Direito das Coisas. $18^{\mathrm{a}}$ ed. São Paulo: Saraiva, 2002.

GONÇALVES, Carlos Roberto. Direito das Coisas, volume 3. Sinopses Jurídicas. São Paulo: Saraiva, 2003.

LANNA, Ana Lúcia Duarte. Uma Cidade na Transição. Santos: 1870-1913. São PauloSantos: Hucitec-Prefeitura Municipal de Santos, 1996.

MEIRELLES, Hely Lopes. Direito Administrativo Brasileiro. 27ª ed, São Paulo: Malheiros, 2002 ,

NERY, Rosa M. de Andrade; VIANA, Rui G. Camargo (orgs.). Temas Atuais de Direito Civil na Constituição Federal: Da função social para responsabilidade da empresa. São Paulo: RT, 2000. 